\title{
ANALYSIS OF THE EFFECT OF FUNDAMENTAL FACTORS AND ITS IMPLICATIONS ON DEVIDEND PAYOUT RATIO
}

\author{
Sawukir \\ Universitas Pamulang, Tangerang Selatan, Indonesia \\ dosen02319@unpam.ac.id
}

\begin{abstract}
Fundamental factors have a strong influence on Earning Per Share because fundamental factors indicate the company's financial performance. The purpose of this study was to determine the effect of current ratio (CR), return on equity (ROE) and debt to equity ratio (DER) on earnings per share (EPS) and its implications for the dividend payout ratio (DPR) in pharmaceutical companies in the Malaysian stock exchange period $2012-2016$ partially and simultaneously. The study was conducted using descriptive statistical methods and panel data regression methods. The sampling technique used was purposive sampling with a sample of 40 samples. The research data is secondary data obtained from www.bursamalaysia.com for the period 2012-2016. Testing the research hypothesis using a common effect model with the e-views version 9 application tool. The results in this study shows that the Growth of Current Ratio, return on Equity, Debt to Equity Ratio, Earning Per Share and Dividend Payout Ratio in pharmaceutical companies fluctuate every year. In Partial Current Ratio there is no significant effect on the variable Earning Per Share. In Partial Return On Equity has a significant effect on Earning Per Share. In real terms Debt to Equity Ratio has no significant effect on Earning Per Share. Simultaneously and together the variables Current Ratio, Return On Equity and Debt to Equity Ratio have a significant effect on Earning Per Share. Partially Earning Per Share has a significant effect on Dividend Payout Ratio.
\end{abstract}

Keywords: Current Ratio; Return On Equity; Debt to Equity Ratio; Earning Per share and Dividend Payout Ratio

\section{INTRODUCTION}

The main purpose of the company are to enhance and maximize the benefit of the owners of it (Andriyanto, Effriyanti \& Hidayat, 2018). The net profit of the company is one of the advantages of the company, while the company owner benefits reflected in earnings for shareholders of the ordinary or that is often referred to as the Earning Per Share (EPS). EPS indicates how large the company's ability to provide refund to the owner of the company. It is therefore interesting EPS for shareholders because it is an indicator that is often used to measure a company's success in achieving the advantages of each of the shares invested (Shita, 2014:1).

Research conducted by Mudjijah (2015: 1) shows the influence between $\mathrm{CR}$ and EPS. But it is different from the research conducted 
by (Shita, K., 2014: 10) which shows that CR does not affect EPS.

According to Jatmiko, small DERs can affect trust in long-term creditors because they are able to fulfill longterm obligations. That way shareholders can feel safe in investing their funds in the company, and will affect the amount of funds to be invested (Jatmiko, 2009: 7).

Research conducted by (Shita, 2014: 8) which shows that DER has an effect on EPS, but different from research conducted by (Hanafiah, 2014: 1) which shows that DER has no effect on EPS.

A ratio that shows how much the company can generate profits or profits from the results of the management of its capital, both its own capital and capital from investors is Return On Equity (ROE). If ROE is high, then the company has been effective in managing its capital so that it will attract interest and trust investors to invest. The phenomenon that occurs is the total assets and total equity increased along with net income has increased as well, meaning that the higher the assets it will show how rich the company. This will affect the ease of the company's management process to obtain loans from other companies.

Research conducted by (Nugroho, H. and Ichsan, 2011: 1) states that ROE has an effect on EPS, while research conducted by (Diaz and Jufrizen, 2014: 7) states that ROE does not affect EPS.

Dividend Payout Ratio (DPR) according to Suhadak and Handayani, (2014: 2) namely the percentage of profits paid in the form of dividends. Factors that influence company decisions in determining the amount of profit to be distributed as dividends include: profitability, liquidity, solvency, and activity. The large consideration of a DPR is thought to be closely related to a management performance because a company's financial performance is quite good and of course it can be expected to determine the size of the DPR in accordance with the expectations of shareholders who have invested in the company.

Research conducted by (Diantini and Bagira, 2016: 1) which showed that earning per share payout ratio. dividend influences. But in contrast to research conducted by (Chatarina, 2016: 1) which showed that EPS will not affect. dividend payout ratio. Here are the data on variables would check the following:

Table 1: Average, CR ROE, DER, EPS and The Representatives in The Pharmaceutical Company in Malaysia

\begin{tabular}{|ccccccc|}
\hline No & Tahun & $\begin{array}{c}C R \\
(x)\end{array}$ & $\begin{array}{c}\text { ROE } \\
(\%)\end{array}$ & $\begin{array}{c}\text { DER } \\
(\%)\end{array}$ & $\begin{array}{c}\text { EPS } \\
(\text { sen })\end{array}$ & $\begin{array}{c}\text { DPR } \\
(\%)\end{array}$ \\
\hline 1 & 2012 & 2,20 & 15,25 & 51,82 & 18,32 & 42,12 \\
2 & 2013 & 2,50 & 16,89 & 46,73 & 18,63 & 37,65 \\
3 & 2014 & 2,59 & 13,71 & 40,27 & 20,64 & 32,92 \\
4 & 2015 & 2,54 & 12,38 & 46,38 & 19,13 & 40,10 \\
5 & 2016 & 2,28 & 8,34 & 49,04 & 15,31 & 37,54 \\
\hline
\end{tabular}

From the data above, it can be seen that the value of CR from 2012 2016 has fluctuated, where the highest CR value occurred in 2014 which was $2.59 \mathrm{X}$ and the lowest $\mathrm{CR}$ value in 2012 was $2.20 \mathrm{X}$. ROE value from 2012 - 2016 also experienced fluctuations, where the highest ROE value occurred in 2013 which was $16.89 \%$ and the lowest ROE in 2016 was $8.34 \%$. The DER 
value from 2012-2016 also fluctuated, where the highest DER value occurred in 2012 which was $51.82 \%$ and the lowest DER value occurred in 2014 which was $40.27 \%$. The EPS value also fluctuated, where the highest EPS value occurred in 2014 at 20.64 cents, while the lowest EPS value occurred in 2016 which was 15.31 cents. The DPR's value from 2012 - 2016 also fluctuated, where the highest value of DPR occurred in 2012 , which was $42.12 \%$

\section{LITERATURE REVIEW}

\subsection{Management}

Management is a process of organizing various activities in the framework of the implementation of the goals and as the ability or skills of the people who occupy managerial position to acquire something of the results in order of achievement of goals through the activities of others (Feriyanto and Triana, 2015:4).

According to the (Athoillah, 2013:13) management is concerned with the process of planning, organizing, leadership and control over which there is an attempt to achieve the goal of member organizations that have been set by exerting the resources of the organization.

Understanding management according to (Amirullah, 2015:5) refers to efforts to move the Organization through the implementation of the functions of planning, organizing, direction and control in order to achieve the goals of the Organization efficiently and effective (Hidayat \& Yuliah, 2018). and the lowest value of DPR occurred in 2014, which was $32.92 \%$.

The authors are interested in conducting research entitled: "Analysis of the Effect of CR, ROE, DER to EPS and Its Implications to Dividend Payout Ratio in Pharmaceutical Companies Listed on Malaysian Stock 2012-2016 Period based on the background of the problem and the empirical data of the company above.

According to Usman (2013:6) was a series of management activities directed use of resources of the Organization effectively and efficiently in order to achieve the goals of the organization. Hasibuan (2016:2) stated that management is the science and art of regulating the process of exploiting human resources and other resources effectively and efficiently to achieve specific objectives.

\subsection{Financial Management}

Based on statements from James and Wachowicz (Marlina \& Clara, 2009:3) financial management pertaining to the acquisition, funding and management of assets with some general purpose and background. Financial management is all activities related to acquisition, funding and management of assets with some overarching goal (Kasmir, 2013:5).

\subsection{Financial Report}

Financial report a summary report, which is useful for users of financial statements for decision making (Wild, Larson, Chiappetta, 2007:17). 
According to Kasmir (2015:7), the financial statements report of the historical achievements of a company and provide the basis, along with business analysis and economic forecasting, for projection and for the future. Financial statements portray the financial company outposts earned in one period. In practice, the three basic financial statements are known, namely the financial balance sheet, profit loss report cash flow statement.

\subsection{Financial Ratio}

Financial ratio is an activity comparing the figures that exist in the financial statements by means of dividing one number with another number (Kasmir, 2015:104). Each financial ratio has a purpose, usefulness and sense, then any results of the measured ratio is interpreted so that it becomes more meaningful to decision making.

\section{RESEARCH METHOD}

An object in this research are a pharmaceutical company who have enrolled in Malaysian Stock exchange that met the criteria of the sampling method of purposive, namely the company which has a complete set of years 2012-2016 financial report. Research with an object in the form of a pharmaceutical company are a pharmaceutical company investor are very interested in at home or abroad.

Types of data used in this research is secondary data. According to Mustafa, (2009:92) secondary data is data that has been collected and the other party has been documented so just copy the data for the purposes of research. Secandary data are obtained in the form of the annual report and the audited financial statements of the pharmaceutical companies that have listed on Bursa Malaysia in 2012-2016. Data sourced from the official website of Bursa Malaysia in www.Bursa Malaysia.com, www.malaysiastock.biz, www.Bloomberg.com, library, books, researchers earlier journals, that support this research and other sources.

\subsection{Data Collection Techniques}

The method of data collection carried out to collect data in this study is the method of documentation. The data in the study are data panels, namely the merging of time series data with cross section data (Sriyana, 2014: 11). Time series data is data that provides value information from time to time. While the cross section is data that provides about individual changes at a given moment.

\subsection{Operational Definitions of Variables}

In this study there are five variables examined, namely the free variable (independent) is a Current Ratio (X1), Return On equity (X2), Debt to Equity Ratio (X3), variable (dependent) is Earning Per Share (Y) and variable $(\mathrm{Z})$ is Dividend payout Ratio.

\subsection{Sample Collection Techniques}

On the method of withdrawal of samples in this study is the method of withdrawal sample nonprobabilita (nonprobability sampling) by using a 
purposive sample withdrawal technique (purposive sampling) is to define the specific criteria. As for the sample criteria, among others:

a. The pharmaceutical companies listed on Bursa Malaysia in the period 2012-2016.

b. The financial statements used are annual report (annual report) and the ringgit in units have been audited.

c. Financial report shows the positions of profit over a period of years 2012-2016.

\subsection{Data Analysis Techniques}

Panel data regression model provides an alternate, common effect, fixed effects and random effects. Using model effect and fixed effects common approach to Ordinary Least Squared (OLS) in the technique of estimasinya, whereas the Random Effect using a Generalized Least Squares (GLS).

\section{RESULTS DISCUSSION}

AND

A classic assumption test is a requirement for multiple regression to analyze statistics based on ordinary lest square (OLS). This classic assumption test aims so that the regression results meet the criteria the best linear Unbiased Estimator (BLUE).

The research was based on a test of the Lagrange Multiplier Test and Chow already made, obtained results that are suitable for use is the data pane by using a common model effect.

Table 2: results of Testing Hypotheses against the dependent Variable independent variable with the Model Common Effect

\begin{tabular}{|c|c|c|c|c|}
\hline \multicolumn{3}{|c|}{$\begin{array}{l}\text { Dependent Variable: EPS } \\
\text { Method: Panel Least Squares } \\
\text { Date: } 12 / 25 / 17 \text { Time: } 16: 58 \\
\text { Sample: } 20122016 \\
\text { Periods included: } 5 \\
\text { Cross-sections included: } 8 \\
\text { Total panel (balanced) observations: } 40\end{array}$} & \multirow[b]{2}{*}{ t-Statistic } & \\
\hline Variable & $\begin{array}{r}\text { Coefficie } \\
\text { nt }\end{array}$ & Std. Error & & Prob. \\
\hline $\mathrm{C}$ & 4.108959 & 4.768697 & 0.861653 & 0.3946 \\
\hline CR & -0.327327 & 1.828806 & -0.178984 & 0.8590 \\
\hline ROE & 44.44019 & 3.631010 & 12.23907 & 0.0000 \\
\hline DER & 6.304725 & 4.574680 & 1.378178 & 0.1767 \\
\hline R-squared & 0.843222 & \multicolumn{2}{|c|}{ Mean dependent var } & 10.04600 \\
\hline Adjusted R-squared & 0.830158 & \multicolumn{2}{|c|}{ S.D. dependent var } & 2.610650 \\
\hline S.E. of regression & 1.075899 & \multicolumn{2}{|c|}{ Akaike info criterion } & 3.078830 \\
\hline Sum squared resid & 41.67213 & \multicolumn{2}{|c|}{ Schwarz criterion } & 3.247718 \\
\hline Log likelihood & -57.57660 & \multicolumn{2}{|c|}{ Hannan-Quinn criter. } & 3.139895 \\
\hline F-statistic & 64.54156 & \multicolumn{2}{|c|}{ Durbin-Watson stat } & 1.896534 \\
\hline Prob(F-statistic) & 0.000000 & & & \\
\hline
\end{tabular}

* Corresponding author's e-mail:dosen02139@unpam.ac.id http://openjournal.unpam.ac.id/index.php/EAJ 
Through a panel data regression test with a model Common effect in table 2 above obtained coefficient has a value of 4.108959 is the constant, while the regression coefficient for the value of the variable 0.327327 of the $C R$, the regression coefficient of the variable ROE of the regression coefficient, variable 44,44019 DER of 6,304725. Then the equation of regression is:

$\mathrm{EPS}=4,108959-0,327327$

$44.44019+\mathrm{CR}+6,304725 \mathrm{DER}$

ROE

Having obtained the results panel data regression test with a common effect in table 4.11 with the above equation performed a test of the hypothesis which consists of testing the coefficient of Determination (Adjusted R Square), the $\mathrm{F}$ test and $\mathrm{t}$ test table 4.11. from the obtained results as the following:

\subsection{Determination Of Coefficient Value}

In table 2 is 0.843222 which means $84.3222 \%$ variation of the variable probability of Earning Per Share can be explained by three independent variables that exist. $15.6778 \%$ probability of Earning Per Share is explained by other variable that is not observed in this study.

\subsection{F-test}

Based on table 4.1 results of regression test for testing the influence of Current Ratio, Return On Equity and Debt to Equity Ratio towards Earning Per share, in the probability values can be (significant) 0.05 , then $<0.00000 \mathrm{H} 0$ is rejected and the $\mathrm{H} 1$ is accepted. This shows that the Current Ratio, Return On Equity and Debt to Equity
Ratio simultaneously and together influenced significantly to Earning Per Share.

\subsection{Test-t}

Do test-t to know influence of partially independent variable affect the dependent variable was significant.

- If the value is significant $>0.05$ $\mathrm{H} 0$ and $\mathrm{H} 1$ is accepted then rejected.

- If the value is significant $\mathrm{HO}$ is rejected then the $0.05<$ and $\mathrm{H} 1$ are accepted.

The test of Hypothesis 1: the influence of Current Ratio against the Earning Per Share

H0: Current Ratio not significantly influential towards Earning Per Share.

H1: Current Ratio significantly influential to Earning Per Share.

The results of the regression analysis showed that the test value probability (significance) Earning Per Share is $0.8590 .0,8590>0.05$, then $\mathrm{H} 0$ and $\mathrm{H} 1$ accepted rejected. The condition indicates that the variable Current Ratio was not significant influential variable against the Earning Per Share.

\subsection{Test the influence of Earning Per Share against the Dividend Payout Ratio}

The last test was done-t to know how partial influence Earning Per Share $(\mathrm{Y})$ against a Dividend Payout Ratio $(Z)$. the hypothesis that is used for this test:

H0: variable Earning Per Share partially affecting Dividend Payout Ratio significantly to 
H1: variable Earning Per Share partially significant effect against the Dividend Payout Ratio.

With decision making:

- If the level of 0.05 significance $>$ $\mathrm{H} 0$ and $\mathrm{H} 1$ is accepted then rejected.

- if the level of the significance of $\mathrm{H} 0$ is rejected then the $0.05<$ and $\mathrm{H} 1$ are accepted.

\subsection{Discussion}

4.2.1. The influence of Current Ratio against the Earning Per Share on pharmaceutical companies.

Based on the results of hypothesis testing the influence of Current Ratio against the Earning Per Share is obtained probability value (significance) $0.8590>0.05$, then $\mathrm{H} 0$ and $\mathrm{H} 1$ accepted rejected. The condition indicates that the variable Current Ratio was not significant influential variable against the Earning Per Share on pharmaceutical companies.

This is in contrast to research conducted by (Kumala Shita and Herry Laksito, 2014) stating that the Current Ratio has no effect against the Earning per share, but this research agreed with research conducted by Mudjijah (2015) and stating that the Current Ratio effect on Earning per share (Hanafiah, 2014).

\subsubsection{The influence of Return on} Equity (ROE) of Earning Per Share (EPS) on pharmaceutical companies.

Based on the results of hypothesis testing shows that the value of the probability (of significance) 0.0000
0.05 , then $<\mathrm{H} 0$ is rejected and the $\mathrm{H} 1$ is accepted. The condition indicates that the variable is Return On Equity significantly to influential variables are Earning Per Share.

This is in accordance with the research conducted by the (Herbirowo Nugroho and Ichsan Taufikul, 2011) and (Kumala Shita and Herry Laksito, 2014) stating that the Return On Equity to Earning Per Share, but research flips with research conducted by (Jufrizen Diaz and Rafika, 2014) stating that the Return On Equity has no effect against the Earning Per Share.

The higher the Return on Equity (ROE) shows the more efficient companies in using its own capital to generate profit or net profit after tax. Therefore, an increase in the Return on Equity (ROE) is a positive signal to increase the attraction of investors against the company as the verdict to invest and the company that much sought after by investors because of the level of return on revenues will be even greater.

\subsubsection{Influence of Debt To Equity Ratio on Earning Per Share in pharmaceutical companies.}

Based on the results of a regression hypothesis test indicating that the probability value (significance) is $0.1767>0.05$, then the $\mathrm{H} 0$ is rejected and $\mathrm{H} 1$ is accepted. The condition indicates that the affected Debt to Equity Ratio variable is not significant to an Earning Per share variable.

This is contrary to research conducted by (Nugroho and Taufikul, 2011) stating that DEBT To Equity Ratio has no effect on Earning Per Share. But according to 
the research conducted by (Kumala Shita and Herry Laksito, 2014) stating that DEBT to Equity Ratio has an effect on Earning Per Share.

\subsubsection{The Archiver current Ratio,} Return On Equity and Debt to Equity Ratio on Earning Per Share simultaneously on pharmaceutical companies

Based on the hypothesis test results obtained the probability value (significance) $0,0000<0.05$, then $\mathrm{H} 0$ rejected and $\mathrm{H} 1$ accepted. Description that the Earning Per Share variable is of significance to the Dividend Payout Ratio in pharmaceutical companies.

This is in accordance with the research conducted by (Diantini and Bajra, 2016) stating that Earning Per Share has an effect on the Dividend Payout Ratio.

\section{CONCLUSION}

Based on the results of research and discussion that has been done in the research on "influence Current Ratio, Return On Equity and Debt to Equity Ratio to Earning Per Share and its implications on the Dividend Payout Ratio in pharmaceutical companies Registered in Bursa Malaysia period 2012-2016, can be in the draw of conclusions as follows:

1. The effect of Current Ratio ((X1) is not significant to Earning Per Share.

2. Return On Equity (X2) is a significant impact on Earning Per Share.

3. Debt To Equity Ratio (X3) has no significant impact on Earning Per Share.

4. Influence of Current Ratio, Return On Equity and Debt To Equity Ratio simultaneously significantly affect Earning Per Share.

5. Earning Per Share (Y) affects the Dividend Payout Ratio.

\section{REFERENCES}

Andriyanto, R., Effriyanti, E., \& Hidayat, A. (2018). The Effect of Spiritual Intelligence (SQ) and Personality Types on Auditor's Ability to Detect Fraud. JABI (Jurnal Akuntansi Berkelanjutan Indonesia), 1(3), 258-268.

Amirullah, (2015), Pengantar Manajemen Fungsi-prosesPengendalian, Jakarta, Mitra Wancana Media.
Athoillah, Anton, (2013), DasarDasar Manajemen, Bandung, CV Pustaka Setia.

Hanafiah, M. Ali, (2014), Pengaruh Current Ratio, Quick Ratio, Inventory Turnover, Total Aset Turnover, Debt To Equity Ratio Tehadap Earning Per Share Pada Perusahaan Industri Barang Konsumsi Yang Terdaftar Di Bursa Efek Indonesia Periode 2009 - 2012, 
Jurnal Fakultas Ekonomi Universitas Maritin Raja Ali Haji, Tanjung Pinang.

Hasibuan, Malayu, (2016), Manajemen Dasar, Pengertian dan Masalah,

Edisi Revisi, Jakarta, Bumi Aksara.

Hidayat, A., \& Yuliah, N. (2018). The Effect of Good Corporate Governance and Tax planning on Company Value. $E A J$ (Economics and Accounting Journal), 1(3), 234-241.

Kumala, Shinta, (2014), Pengaruh Kinerja Keuangan, Ukuran Perusahaan dan Arus Kas Operasi Terhadap Earnings Per Share, Diponegoro Journal of Accounting, 3(2)

Mudjijah, Slamet, (2015), Analisis Pengaruh Faktor- Faktor Internal Perusahaan Terhadap Earning Per Share, Jurnal Ekonomi dan Manajemen, 4(2).

Mustafa, Zainal, (2009), Mengurai Variabel hingga Instrumentasi, Yogyakarta, Graha Ilmu.

Bumi Aksara, Jakarta.

Wild, Larson, Chiappetta, (2007), Financial and Managerial
Nugroho, Herbirowo dan Taufikul, Ichsan, (2011), Pengaruh Return On Equity dan Debt To Equity Terhadap Earning Per Share, Jurnal Ekonomi dan Bisnis, 11(1)

Diantini, Olivia dan Bajra, Ida Bagus, (2016), Pengaruh Earning Per Share , Pertumbuhan Perusahaan dan Current Ratio Terhadap Kebijakan Deviden, Jurnal Manajemen Unud, 5(11)

Rafika, Diaz dan Jufrizen, (2014), Pengaruh Return On Asset dan Return On Equity terhadap Earning Per Share pada Perusahaan Asuransi Yang Terdaftar Di Bursa Efek Indonesia, Jurnal manajemen dan Bisnis, 14(2)

Sriyana, J, (2014), Metode Regresi Data Panel, Ekonisia, Yogyakarta.

Usman, Husaini, (2013), Manajemen, Teori, Praktik, dan Riset Pendidikan, Edisi 4 Cetakan

Accounting, International Edition, Mc-Graw-Hill, Singapore. 